К. В. Лаврентьєва, Н. В. Черевач, А. І. Вінніков

Дніпропетровський національний університет ім. Олеся Гончара

\title{
ЗАКОНОМІРНОСТІ РОСТУ ФОСФАТМОБІЛІЗУВАЛЬНИХ БАКТЕРІЙ У РІЗНИХ ТИПАХ ЖИВИЛЬНИХ СЕРЕДОВИЩ
}

Досліджено закономірності розвитку двох штамів грунтових фосфатмобілізувальних бактерій Pseudomonas putida та Enterobacter dissolvens у різних типах живильних середовищ. Побудовано криві росту культур і визначено їх фізіологічні параметри. Показано, що кращий ріст досліджених штамів спостерігається в м'ясопептонному бульйоні, ніж у мінеральному рідкому середовищі, причому більше накопичення життєздатних клітин характерне для $E$. dissolvens. Під час росту культур відбувається зниження $p H$ елективного мінерального середовища з 7,0 до 4,4-4,5, а $p H$ бульйону залишається незмінним на рівні 7,0 протягом усього терміну культивування.

Е. В. Лаврентьева, Н. В. Черевач, А. И. Винников

Днепропетровский национальный университет им. Олеся Гончара

\section{ЗАКОНОМЕРНОСТИ РОСТА ФОСФАТМОБИЛИЗИРУЮЩИХ БАКТЕРИЙ В РАЗЛИЧНЫХ ТИПАХ ПИТАТЕЛЬНЫХ СРЕД}

Исследованы закономерности развития двух штаммов почвенных фосфатмобилизирующих бактерий Pseudomonas putida и Enterobacter dissolvens в различных типах питательных сред. Построены кривые роста культур и определены их физиологические параметры. Показано, что лучший рост исследуемых культур наблюдается при их развитии в мясопептонном бульоне, чем в минеральной жидкой среде, при этом большее накопление жизнеспособных клеток характерно для $\boldsymbol{E}$. dissolvens. Во время роста культур происходит снижение $p H$ элективной минеральной среды с 7,0 до 4,4-4,5, a pH бульона остается неизменным на уровне 7,0 на протяжении всего термина культивирования.

K. V. Lavrentyeva, N. V. Cherevach, A. I. Vinnikov

Oles' Gonchar Dnipropetrovsk National University

\section{REGULARITIES OF PHOSPHATE-MOBILIZING BACTERIA GROWTH IN DIFFERENT MEDIA}

Regularities of two strains of soil phosphate-mobilizing bacteria growth were investigated in different media. Curve of growth and physiological parameters were defined for Pseudomonas putida and Enterobacter dissolvens. Growth pattern of investigated strains was better in the broth medium than in mineral. In these conditions higher concentration of viable bacterial cells was common for $E$. dissolvens. It was shown that during cultivation $\mathrm{pH}$ of mineral medium went down to 4.4-4.5, but broth medium had constant $p H$ 7.0.

\section{Ветуп}

Основне завдання будь-якого біотехнологічного процесу - отримання максимальної кількості мікробної біомаси продуцента або цільового продукту [2]. При розробці технологічної схеми отримання біопрепаратів на основі фосфатмобілізувальних бактерій для поліпшення фосфорного живлення сільськогосподарських рослин -

(C) К. В. Лаврентьєва, Н. В. Черевач, А. І. Вінніков, 2010 
ських рослин - одного з перспективних напрямів сучасного біотехнологічного виробництва $[5 ; 8]$ - необхідно враховувати ефективність росту штамів у промисловому середовищі, оскільки розвиток культур залежить від його складових [7]. Елективні середовища для вирощування фосфатмобілізувальних бактерій, на яких проводиться дослідження динаміки мобілізації фосфатів, є відносно «бідними». У той же час для реалізації головного завдання виробництва біопрепаратів необхідно підібрати ростове середовище для отримання значної кількості мікробної біомаси за мінімальний час культивування. Ефективність росту промислових штамів оцінюють за параметрами росту: максимальною кількістю клітин у стаціонарній фазі, тривалістю лаг-фази, питомою швидкістю росту, часом генерації тощо [4]. У зв'язку з цим мета даної роботи охарактеризувати закономірності розвитку двох штамів грунтових фосфатмобілізувальних бактерій Pseudomonas putida та Enterobacter dissolvens у різних типах живильних середовищ та відібрати більш ефективне для накопичення значної кількості мікробної біомаси.

\section{Матеріал і методи досліджень}

Об’єкт дослідження - два штами грунтових фосфатмобілізувальних бактерій P. putida та E. dissolvens із колекції культур кафедри мікробіології та вірусології ДНУ ім. Олеся Гончара. Із метою вивчення закономірностей їх росту штами E. dissolvens i $P$. putida вирощували у м'ясопептонному бульйоні (МПБ) та рідкому елективному середовищі Менкіної [6] на шутелі при 2200 об./хв при температурі $+28{ }^{\circ} \mathrm{C}$ протягом 7 діб. Інокулятом слугували 12-годинні бульйонні культури, які вносили до середовищ у концентрації $10^{7}$ кл./мл. Для побудови кривих росту відбір проб у першу добу культивування проводили кожні 4 години. Кількість життєздатних клітин (колонієтвірних одиниць) визначали методом Коха [3].

Для дослідження параметрів росту (тривалості лаг-фази, питомої швидкості росту, часу генерації та максимальної кількості клітин у стаціонарній фазі росту), які визначали загальноприйнятим способом, проби відбирали кожної години [4].

\section{Результати та їх обговорення}

При дослідженні закономірностей росту штамів у елективному середовищі Менкіної із трикальційфосфатом і в МПБ встановлено, що динаміка розвитку культур значно відрізнялася залежно від типу живильного середовища та властивостей штамів (рис. 1 і 2). Інтенсивніший ріст і накопичення біомаси характерні для штаму E. dissolvens як у МПБ, так і в елективному середовищі із трикальційфосфатом.

Незважаючи на те, що тривалість лаг-фази (період адаптації штамів до умов середовища) для P. putida у МПБ становила лише 1,5, а для E. dissolvens - 2,0 години, інші параметри росту значно вищі для останнього штаму (табл. 1). Константа швидкості поділу для $E$. dissolvens становила 1,5 клітинних поділів за годину, час генерації склав 0,7 години, а максимальна концентрація клітин у стаціонарі дорівнювала 10,70 $\mathrm{lg}$ КУО. Для P. putida ці показники становили відповідно 1,4 поділів за годину, 0,7 години, $9,86 \lg$ КУО.

Менш придатне для росту штамів (особливо для псевдомонади) елективне середовище. Тривалість лаг-фази у $P$. putida збільшилась на 2,5 години, тоді як у E. dissolvens лише на одну. Разом із тим змінилися й інші параметри росту культур: константа швидкості поділу E. dissolvens зменшилася з 1,5 до 0,7, для псевдомонади з 1,4 до 0,4 клітинних поділів за годину; подовжився час генерації відповідно до 1,5 і 
2,3 години; у стаціонарній фазі росту максимальна кількість життєздатних клітин E. dissolvens становила 9,92 lg КУО, а P. putida-8,60 lg КУО.
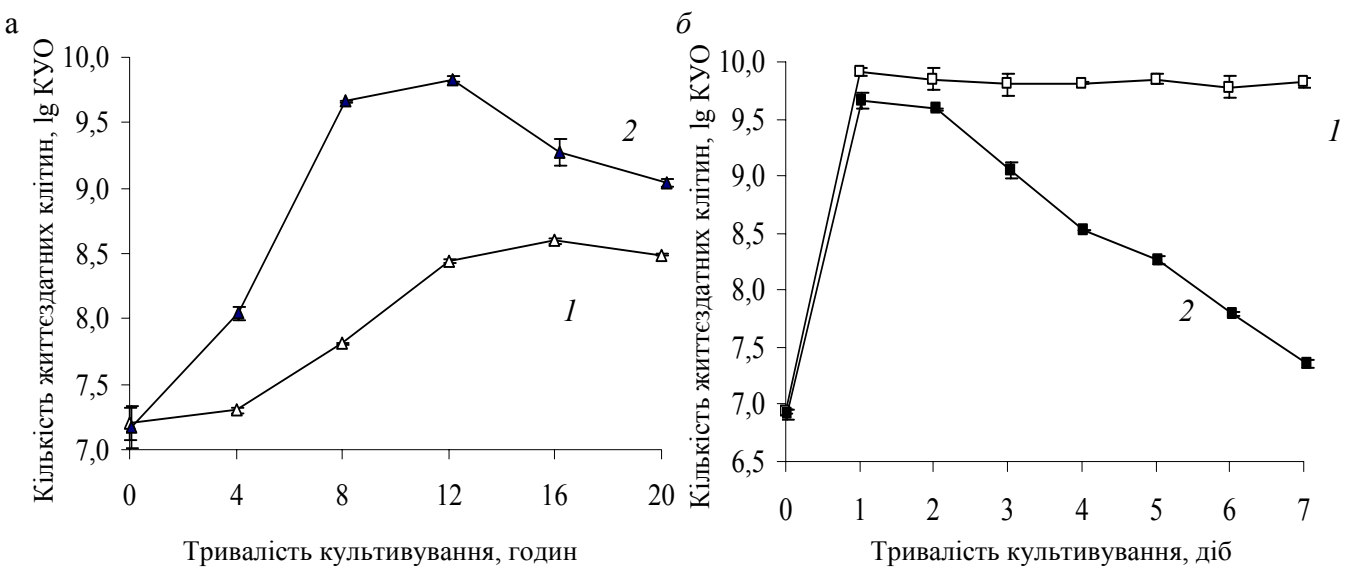

Рис. 1. Динаміка росту Pseudomonas putida у живильних середовищах Менкіної та МПБ $(n=3)$ : $a$ - протягом першої доби культивування, $\sigma$ - протягом 7 діб культивування; 1 - елективне середовище із трикальційфосфатом, 2 - МПБ
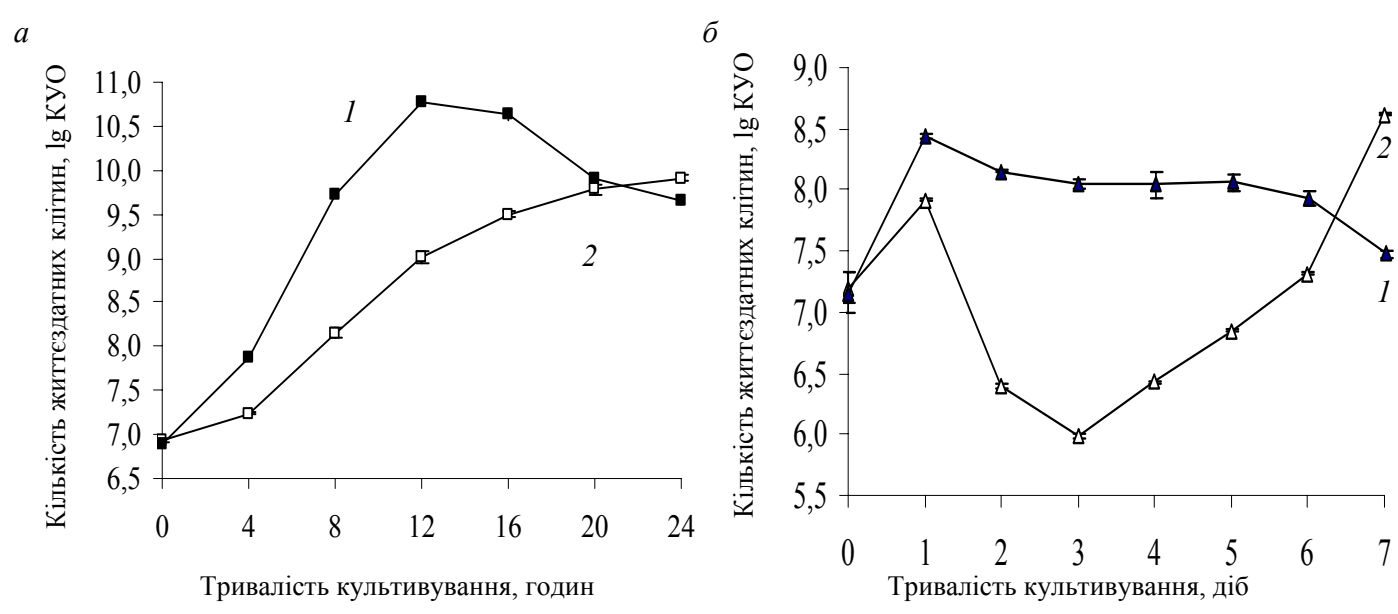

Рис. 2. Динаміка росту Enterobacter dissolvens у живильних середовищах Менкіної та МПБ (n=3): $a$ - протягом першої доби культивування, $\sigma$ - протягом 7 діб культивування;

1 - елективне середовище із трикальційфосфатом, 2 - МПБ

Уповільнення ростових процесів при культивуванні штамів у елективному середовищі призвело і до зростання тривалості фаз розвитку культур. Для E. dissolvens при культивуванні у МПБ тривалість експоненційної фази становила 6-7 годин, а стаціонарна фаза наставала на 12-ту годину росту (див. рис. 2).

Таблиия 1

Фізіологічні параметри росту штамів Enterobacter dissolvens та Pseudomonas putida $(n=3)$

\begin{tabular}{|l|c|c|c|c|c|c|c|c|}
\hline \multirow{3}{*}{ Штами } & \multicolumn{2}{|c|}{$\begin{array}{c}\text { Тривалість лаг-фази, } \\
T_{\text {lag, год. }}\end{array}$} & $\begin{array}{c}\text { Константа швидкості } \\
\text { поділу, } v \text { кількість } \\
\text { поділів/год. }\end{array}$ & \multicolumn{2}{|c|}{$\begin{array}{c}\text { Час генерації, } \\
g, \text { год. }\end{array}$} & $\begin{array}{c}\text { Максимальна кількість } \\
\text { життєздатних клітин, } \\
\text { lg КУО }\end{array}$ \\
\cline { 2 - 9 } & МПБ & Менкіної & МПБ & Менкіної & МПБ & Менкіної & МПББ & Менкіної \\
\hline E. dissolvens & 2,0 & 1,5 & 1,5 & 1,4 & 0,7 & 0,7 & 10,70 & 9,86 \\
\hline P. putida & 3,0 & 4,0 & 0,7 & 0,4 & 1,5 & 2,3 & 9,91 & 8,60 \\
\hline
\end{tabular}


При вирощуванні того ж штаму в елективному середовищі Менкіної спостерігали подовження експоненційної фази до 11 годин і досягнення стаціонару на 20-ту годину культивування. Для P. putida експоненційна фаза тривала 6,0-6,5 години при вирощуванні штаму в МПБ і збільшувалась до 9 годин в елективному середовищі. Стаціонар відмічали на 8-му годину культивування псевдомонади в МПБ і на 12-ту годину в елективному середовищі (див. рис. 1).

Таку різницю за характером розвитку штамів і тривалістю фаз росту на різних живильних середовищах можна пояснити впливом складу останніх. Уповільнений характер росту мікроорганізмів на мінеральному середовищі зумовлений часом, необхідним для синтезу ферментів, здатних мобілізувати новий субстрат.

Цікаві результати отримані при культивуванні бактерій протягом 7 діб у МПБ та в елективному середовищі із трикальційфосфатом. Із рисунків видно, що після досягнення стаціонару на 12-ту годину культивування у МПБ розвиток $P$. putida та E. dissolvens поступово пригнічувався, що засвідчує зниження кількості життєздатних клітин штамів з 9,86 8,84 lg до 7,53 $\pm 6,47 \mathrm{lg}$ КУО та з $10,7 \pm 9,48 \mathrm{lg}$ до 7,41 $\pm 6,11 \mathrm{lg}$ КУО, відповідно; $p H$ культуральної рідини для обох штамів зберігався на рівні 7,0 протягом усього терміну культивування.

Зовсім інший розвиток штамів спостерігали у мінеральному середовищі. Для E. dissolvens інтенсивне накопичення життєздатних клітин відмічали практично протягом усього терміну культивування (з 7,0 $\pm 6,1 \mathrm{lg}$ до 9,9 $\pm 9,76 \lg$ КУО). Лише деяке незначне зниження життєздатних клітин (з 9,6 9,85 lg до 9,6 9,42 lg) відбувалось між першою та другою добами культивування.

Під час росту культури відмічені зміни й у значенні $p H$ культуральної рідини (табл. 2). Якщо початковий $p H$ середовища становив 7,0, то вже через 24 години культивування E. dissolvens він знизився на 2,5 одиниці. Протягом подальших 6 діб культивування $p H$ середовища практично не змінювався, його значення підвищилось лише на 0,3 одиниці.

Таблиия 2

Динаміка зміни рН елективного середовища Менкіної

при культивуванні штамів Pseudomonas putida та Enterobacter dissolvens

\begin{tabular}{|l|c|c|c|c|c|c|c|}
\hline \multirow{2}{*}{ Штами } & \multicolumn{7}{|c|}{ Термін культивування, доба } \\
\cline { 1 - 8 } & 1 & 2 & 3 & 4 & 5 & 6 & 7 \\
\hline P. putida & $4,4 \pm 0,06$ & $4,4 \pm 0,02$ & $4,5 \pm 0,10$ & $4,7 \pm 0,05$ & $5,0 \pm 0,10$ & $5,0 \pm 0,05$ & $5,2 \pm 0,10$ \\
\hline E. dissolvens & $4,5 \pm 0,01$ & $4,5 \pm 0,06$ & $4,5 \pm 0,05$ & $4,4 \pm 0,15$ & $4,6 \pm 0,10$ & $4,8 \pm 0,12$ & $4,8 \pm 0,05$ \\
\hline
\end{tabular}

Для культури $P$. putida зниження кількості життєздатних клітин після першої доби культивування було більш різким і на 3-тю добу цей показник становив лише 5,99 $\pm 5,7$ lg КУО. 3 4-ї доби культивування кількість життєздатних клітин знову починала зростати і на 7-му добу досягала значення 8,6 \pm 7,8 $\lg$ КУО. Що стосується змін $p H$ культурального середовища, то вже на 1-шу добу культивування він знизився з 7,0 до 4,4 і не змінювався протягом 3 діб. Починаючи з 4-ї доби відмічене підвищення цього показника на 0,8 одиниці. Таку поведінку культури, вірогідно, можна пояснити репресуванням певних ділянок шляху утилізації глюкози, що входила до складу елективного середовища, кислими продуктами метаболізму (що засвідчувало зниження $p H$ ), які накопичувались під час активного росту штаму. Це призводило до часткового відмирання клітин, на що вказує зниження кількості КУО з 7,92 $\pm 7,47$ lg до 5,99 $\pm 5,7 \mathrm{lg}$. При поступовому підвищенні $p H$ створювались умови, сприятливі для подальшого розвитку штаму. 
3 іншого боку, відновлення росту псевдомонад з 4-ї доби культивування можна пояснити вже описаним у літературі механізмом регулювання бактеріями $p H$ (аутостабілізація $p H)$. Відомо, що у деяких мікроорганізмів активний ріст починається при $p H$ середовища 7,0, але при цьому швидко знижується до значення 3,0, а їх внутрішній $p H$ залишається нейтральним. За таких умов культура «намагається» вирівняти концентрацію іонів водню шляхом синтезу нейтральних продуктів, про що свідчить (як і в нашому випадку) поступове підвищення $p H$. Цей процес буде відбуватися до моменту досягнення оптимуму, характерного для даного штаму, при цьому швидкість аутостабілізації є прямопропорційною до концентрації життєздатних клітин [2].

\section{Висновки}

Кращий ріст досліджених штамів спостерігали у м'ясопептонному бульйоні, ніж у мінеральному рідкому середовищі, причому більше накопичення життєздатних клітин характерне для E. dissolvens. Під час росту культур відбувалось зниження $p H$ елективного мінерального середовища з 7,0 до 4,4-4,5 одиниці, а $p H$ бульйону залишався незмінним на рівні 7,0 протягом усього терміну культивування. Доцільне використання м'ясопептонного бульйону для накопичення біомаси досліджених культур із наступним вивченням їх фосфатмобілізувальної активності в елективному середовищі 3 трикальційфосфатом.

\section{Бібліографічні посилання}

1. Арзамасцев А. А. Аутостабилизация $p H$ в периодической культуре Pseudomonas // Микробиология. - 1987. - Т. 55, вып. 6. - С. 985-989.

2. Глик Б. Молекулярная биотехнология. Принципы и применение / Б. Глик, Д. Пастернак. М. : Мир, 2002. -589 c.

3. Методы почвенной микробиологии и биохимии / Д. Г. Звягинцев, И. В. Асеева, И. П Бабьева, Т. Г. Мирчинк. - М. : МГУ, 1980. -224 с.

4. Мікробіологія / М. Г. Сергійчук, В. К. Позур, А. І. Вінніков та ін. - К. : Видавничо-поліграфічний центр «Київський університет», 2005. - 375 с.

5. Мікробні препарати - важливий компонент біологізації вирощування ярої пшениці / В. П. Патика, Є. П. Копилов, Т. І. Патика та ін. // Агроекологічний журнал. - 2004. - № 4. - С. 3-7.

6. Рой А. А. Новые штаммы бацилл, минерализующие органические соединения фосфора / А. А. Рой, Л. В. Булавенко, И. К. Курдиш // Мікробіол. журн. - 2001. - Т. 63, № 4. - С. 9-14.

7. Sridevi M. Phosphate solubilization by Rhizobium isolates from Crotalaria species / M. Sridevi, K. V. Mallaiah, N. C. S. Yadav // Journal of Plant Siences. - 2007. - Vol. 2, N 6. - P. 635-639.

8. Vessey J. K. Plant growth promoting rhizobacteria as biofertilizer // Plant and Soil. - 2003. Vol. 255, N 6. - P. 571-586.

Надійшла до редколегії 12.06.2010 